\title{
MODEL PENENTUAN PEMBELIAN KONDISI MOBIL BEKAS
}

\author{
Fitriana Destiawati ${ }^{1}$, Harry Dhika ${ }^{2}$ \\ ${ }^{1}$ Universitas Indraprasta PGRI \\ J1. Raya Tengah Kel. Gedong, Pasar Rebo Jakarta Timnur 13760 \\ ${ }^{1}$ honeyzone86@gmail.com \\ ${ }^{2}$ Universitas Indraprasta PGRI \\ J1. Raya Tengah Kel. Gedong, Pasar Rebo Jakarta Timnur 13760 \\ 2dhikatr@yahoo.com
}

\begin{abstract}
ABSTRAK
Memiliki mobil merupakan satu hal yang menjadi kebanggaan tersendiri terutama mobil dipilih sesuai dengan kebutuhan pembeli. Banyak sekali hal-hal yang harus diperhatikan ketika membeli sebuah mobil bekas, hal tersebut dikarenakan mobil telah digunakan sebelumnya oleh orang lain dan nilai kualitas barangnya tentunya mengalami penyusutan. Salah satu faktor kenapa harus memilih mobil bekas adalah karena keterbatasan anggran, tentunya ada beberapa hal yang harus diperhatikan dalam membeli mobil bekas. Melalui kajian ini akan diperoleh teknik mendapatkan mobil bekas dengan memperhatikan model yang dibuat dengan algoritma data mining. Sehingga konsumen sebagai pembeli tidak lagi dirugikan akibat beberapa kekurangan atau ketidaktahuan akan kendaraan yang harus dimilikinya dan tidak harus merogoh kocek lebih dalam lagi karena harus mengurus perbaikan yang belum diketahui tapi diperlukan untuk operasional mobil. Teknik klasifikasi menggunakan neural network digunakan sebagai salah satu memilih mobil bekas dengan beberapa attribut yang menjadi bahan pertimbangan. Kajian ini menggunakan evaluasi berupa confusion matrix dan kurva ROC (Recevier Operating Characteristic). Sehingga nilai akurasi diperoleh dengan maksimal dan data dapat di validasi dan diterapkan sebagai model baru dalam menentukanpembelian kondisi mobil bekas. Hasilnya konsumen dapat memutuskan untuk melakukan pembelian terhadap mobil bekas.
\end{abstract}

Kata kunci: Pembelian Mobil Bekas, data mining, Neural Network, Klasifikasi

\section{PENDAHULUAN}

Memiliki sebuah kendaraan merupakan sebuah kebanggaan tersendiri terutama kendaraan beroda 4 atau yang dikenal sebagai mobil. Saat ini semua orang berlomba-lomba untuk membeli atau ingin memiliki kendaraan, tentunya dengan tujuan agar tidak terlalu panas atau kepanasan ketika cuaca panas dan tidak basah ketika kehujanan, selain itu jika sudah berkeluarga, memiliki anggota keluarga yang harus dilindungi dari perubahan cuaca yang tidak menentu akhir-akhir ini.

Saat ini dengan perkembangan teknologi yang maju, tentunya pemikiran konsumen juga semakin baik dalam melakukan pembelian mobil. Mobil yang dipilih dapat diketahui dari berbagai sumber informasi baik itu dari social media atau dari sales yang menawarkan dengan gencar. Seluruh spesifikasi teknik dapat ditinjau lebih awal, seluruh model dan metode atau fasilitas pada mobil dapat diketahui hanya dengan menggerakkan jari dalam internet.

Berkembangnya kemajuan teknologi informasi juga membuat konsumen dalam memilih mobil tidak harus memiliki mobil baru. Mobil baru memberikan banyak sekali fasilitas terkini dengan fitur canggih. Namun dalam mendapatkan mobil baru juga harus merogoh kocek dengan jumlah yang cukup dalam. Hal ini menjadi pertimbangan khusus bagi para konsumen yang ingin memilih mobilnya untuk kepentingan keluarga dan pekerjaannya.

Keinginan dalam memiliki mobil pada dasarnya merupakan hal yang wajar terlebih lagi jika seluruhnya didasarkan pada kebutuhan hidup dan bukan untuk memenuhi gaya hidup. Untuk itu pilihan dalam mengambil mobil bekas atau mobil second hand adalah pilihan terbaik. Melihat banyaknya kebutuhan mendasari bahwa konsumen dituntut harus cerdas dalam melakukan pemilihan mobil bekas.

Mobil bekas bukan berarti suluruh fungsi dan sumber daya yang ada pada mobil tersebut secara garis besar telah habis. Konsumen dapat memperhatikan beberapa hal yang harus dipertimbangkan dalam melakukan pembelian mobil bekas. Walau didasari bahwa mobil merupakan sebuah asset yang menyusut dan semakin lama nilai ekonominya menurun namun tidak berarti seluruh mobil bekas tidak layak untuk digunakan kembali.

Melalui kajian ini akan dilakukan pembahasan dengan menggunakan beberapa attribute dalam pertimbangan untuk membeli mobil bekas. Hal tersebut mendasari adanya kebutuhan konsumen untuk tetap mendapatkan bang yang bagus namun tetap terjangkau.

\section{LANDASAN TEORI}


Kajian dilakukan dengan mempertimbangkan teori sebelumnya yang telah digunakan dalam pemilihan mobil bekas dengan mengembangkan dan berusaha menyempurnakan kajian pemilihan mobil bekas maka digunakan metode dengan konsep data mining.

\section{A. Data Mining}

Data mining atau menambang data didefinisikan sebagai metode yang digunakan untuk mengekstraksi informasi prediktif tersembunyi pada database, ini adalah teknologi yang sangat potensial bagi perusahaan dalam memberdayakan data warehousenya. (Dhika, 2016). Kajian data mining juga sejalan dengan pengolahan data pada Bussines Inteligence (BI). Data BI meliputi perolehan data dan informasi dari berbagai sumber yang bervariasi dan mengolahnya ke dalam pengambilan keputusan. BI dapat digunakan untuk mendukung perusahaan dalam mencapai berbagai kriteria keberhasilan seperti (1) Membantu pembuatan keputusan dengan kecepatan dan kualitas yang lebih baik, (2) Mempercepat operasional, (3) Memperpendek siklus pengembangan produk, (4) Memaksimalkan nilai dari produk yang tersedia dan mengantisipasi peluang baru, dan (5) Menciptakan pasar yang lebih baik dan terfokus, juga meningkatkan hubungan dengan pelanggan dan pemasok (Darudiato, Santoso, \& Wiguna, 2002).

Kajian ini menggunakan konsep klasifikasi, dalam klasifikasi, sasarannya adalah variable kategori, misalkan atribut penghasilan, yang bisa dikategorikan menjadi tiga kelas atau kategori yaitu, tinggi, sedang, dan rendah. Model data mining membaca sejumlah besar record tiap record berisi informasi pada variable target. Contoh, dari sebuah data set misalkan mau mengklasifikasikan penghasilan seseorang yang datanya tidak terdapat pada dataset, berdasarkan karakteristik yang berhubungan dengan orang itu seperti, umur, jenis kelamin, dan pekerjaan. Tugas klasifikasi ini cocok untuk metode dan teknik data mining. Algoritma akan mengolah dengan cara membaca data set yang berisi variable predictor dan variable taget yang telah diklasifikasikan, yaitu penghasilan. Di sini algoritma (software) "mempelajari" kombinasi variable mana yang berhubungan dengan penghasilan yang mana. Data ini disebut training set. Kemudian algoritma akan melihat ke data baru yang belum termasuk klasifikasi manapun. Berdasarkan klasifikasi pada data set kemudian algoritma akan memasukkan data baru tersebut ke dalam klasifikasi yang mana. Misalkan seorang professor wanita berusia 63 tahun bisa jadi diklasifikasikan ke dalam kelas penghasilan tinggi. Algoritma klasifikasi yang banyak digunakan secara luas untuk klasifikasi antara lain, decision tree, bayesian classifier, dan neural network (Gorunescu, 2011)

\section{B. Neural Network}

Neural network adalah (Yu, Haghighat, \& Fung, 2016) satu set unit input/output yang terhubung dimana tiap relasinya memiliki bobot. Berikut ini adalah algoritma neural network.

Langkah pembelajaran dalam algoritma backpropagation adalah sebagai berikut (Hagan, Demuth, \& Beale, 1995):

1. Inisialisasi bobot jaringan secara acak (biasanya antara -0.1 sampai 1.0 )

2. Untuk setiap data pada data training, hitung input untuk simpul berdasarkan nilai input dan bobot jaringan saat itu, menggunakan rumus:

$$
\begin{aligned}
& \text { Input }_{j}=\sum_{i=1}^{n} O_{i} w_{i j}+\Theta_{j} \\
& \text { Keterangan: } \\
& \mathrm{O}_{\mathrm{i}} \quad=\text { Output simpul i dari layer sebelumnya } \\
& \mathrm{W}_{\mathrm{ij}} \quad=\text { bobot relasi dari simpul i pada layer sebelumnya ke simpul } \mathrm{j} \\
& \mathrm{\Theta}_{\mathrm{j}} \quad=\text { bias (sebagai pembatas) }
\end{aligned}
$$

3. Berdasarkan input dari langkah dua, selanjutnya membangkitkan output untuk simpul menggunakan fungsi aktifasi sigmoid:

$$
\text { Output }=\frac{1}{1+\mathrm{e}^{- \text {Input }}}
$$

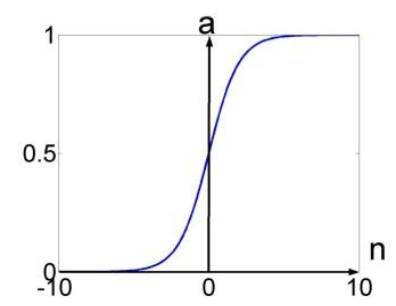

Gambar 2. Fungsi Aktivasi Sigmoid

4. Hitung nilai Error antara nilai yang diprediksi dengan nilai yang sesungguhnya menggunakan rumus:

Error $_{\mathrm{j}}=$ Output $_{\mathrm{j}} \cdot\left(1-\right.$ Output $\left._{\mathrm{j}}\right) \cdot\left(\right.$ Target $_{\mathrm{j}}-$ Output $\left._{\mathrm{j}}\right)$

Keterangan: 
Output $_{\mathrm{j}}=$ Output aktual dari simpul $\mathrm{j}$

Target $_{\mathrm{j}}=$ Nilai target yang sudah diketahui pada data training

5. Setelah nilai Error dihitung, selanjutnya dibalik ke layer sebelumnya (backpropagated). Untuk menghitung nilai Error pada hidden layer, menggunakan rumus:

Error $_{j}=$ Output $_{j}\left(1-\right.$ Output $\left._{j}\right) \sum_{k=1}^{n}$ Error $_{k} w_{j k}$

Keterangan:

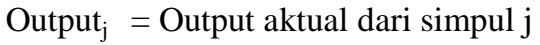

Error $_{\mathrm{k}}=$ error simpul $\mathrm{k}$

$\mathrm{w}_{\mathrm{jk}} \quad=$ Bobot relasi dari simpul $\mathrm{j}$ ke simpul $\mathrm{k}$ pada layer berikutnya

6. Nilai Error yang dihasilkan dari langkah sebelumnya digunakan untuk memperbarui bobot relasi menggunakan rumus

$\mathrm{w}_{\mathrm{ij}}=\mathrm{w}_{\mathrm{ij}}+1 \cdot$ Error $_{\mathrm{j}} \cdot$ Output $_{\mathrm{i}}$

Keterangan:

$\mathrm{W}_{\mathrm{ij}} \quad=$ bobot relasi dari unit $\mathrm{i}$ pada layer sebelumnya ke unit $\mathrm{j}$

$1 \quad=$ learning rate (konstanta, nilainya antara 0 sampai dengan 1 )

Error $_{\mathrm{j}} \quad=$ Error pada output layer simpul $\mathrm{j}$

Output $_{\mathrm{i}}=$ Output dari simpul $\mathrm{i}$

\section{Metode Evaluasi}

Tabel 1. Confusion Matrix Model

\begin{tabular}{|l|l|l|}
\hline \multirow{2}{*}{$\begin{array}{l}\text { Klasifikasi yang } \\
\text { benar }\end{array}$} & \multicolumn{2}{|l|}{ Diklasifikasikan sebagai } \\
\cline { 2 - 3 } & + & - \\
\hline+ & true positives & false negatives \\
- & false positives & true negatives \\
\hline
\end{tabular}

True positives adalah jumlah record positif yang diklasifikasikan sebagai positif, false positives adalah jumlah record negatif yang diklasifikasikan sebagai positif, false negatives adalah jumlah record positif yang diklasifikasikan sebagai negatif, true negatives adalah jumlah record negatif yang diklasifikasikan sebagai negative, kemudian masukkan data uji. Setelah data uji dimasukkan ke dalam confusion matrix, hitung nilainilai yang telah dimasukkan tersebut untuk dihitung jumlah sensitivity (recall), specificity, precision dan accuracy. Sensitivity digunakan untuk membandingkan jumlah TP terhadap jumlah record yang positif sedangkan specificity adalah perbandingan jumlah TN terhadap jumlah record yang negative.

\section{METODE PENELITIAN}

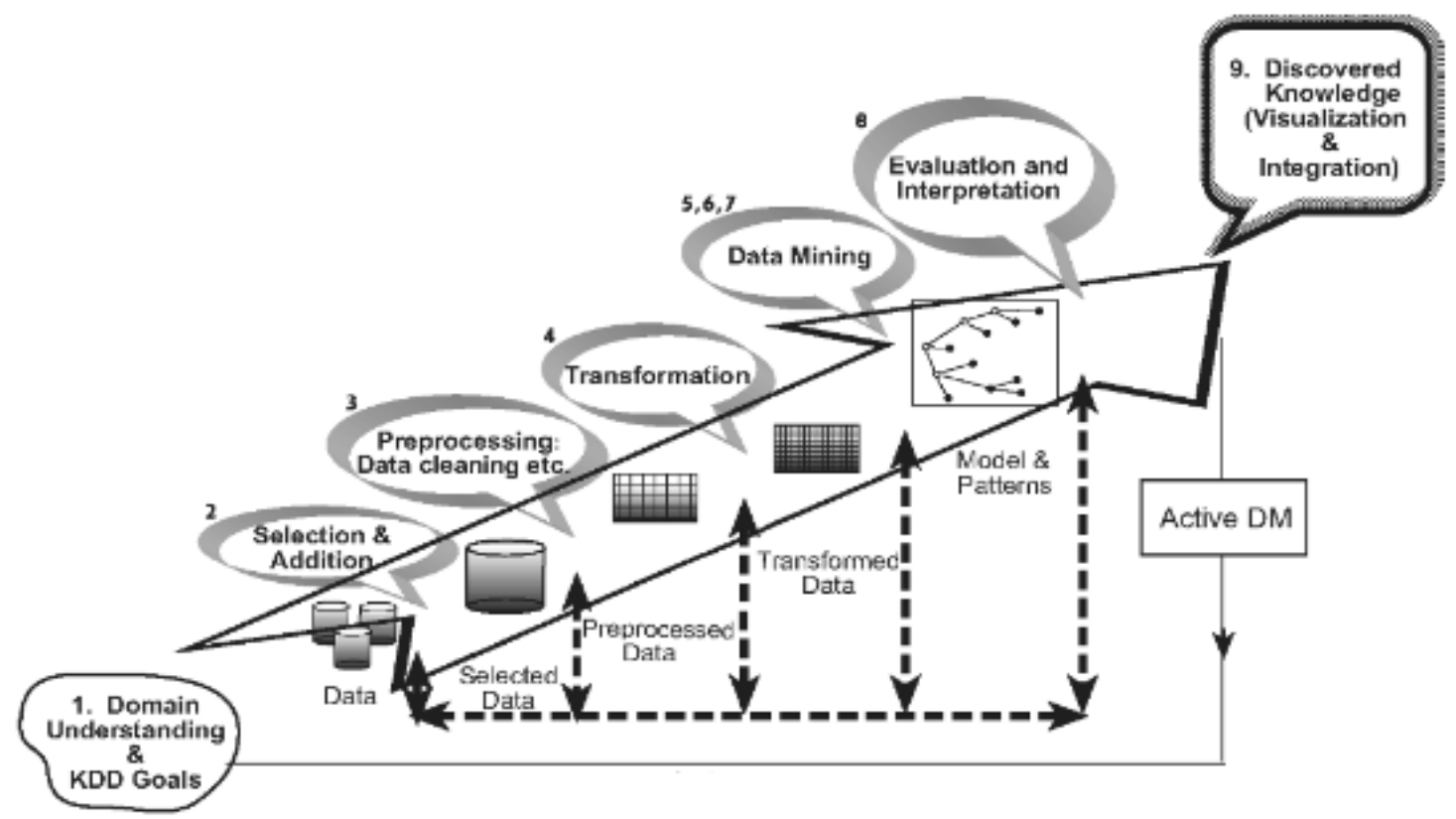

Gambar 1. Langkah-langkah KDD 
Gambar 1. Merupakan langkah-langkah KDD Langkah-langkah dalam KDD (Dhika, Destiawati, \& Fitriansyah, 2016): 1. Pembentukan pemahaman domain aplikasi. Pada tahap ini menentukan tujuan dari end-user dan bagian terkait dimana KDD dilakukan. Mengembangkan pemahaman tentang domain aplikasi ini adalah awal langkah persiapan. Ini mempersiapkan adegan untuk memahami apa yang harus dilakukan dengan banyak keputusan (tentang transformasi, algoritma, representasi, dll). Orang-orang yang bertanggung jawab atas proyek KDD perlu memahami dan menentukan tujuan dari pengguna akhir dan lingkungan di mana pengetahuan penemuan proses akan berlangsung (termasuk pengetahuan awal yang relevan). Sebagai KDD hasil proses, mungkin ada revisi dan perbaikan dari langkah ini. Memiliki memahami tujuan KDD, preprocessing data dimulai, sebagaimana didefinisikan dalam berikutnya tiga langkah (perhatikan bahwa beberapa metode di sini mirip dengan algoritma Data Mining, tetapi digunakan dalam konteks preprocessing) 2. Memilih dan menciptakan satu data set untuk mendukung proses penemuan knowledge akan dilakukan. Penentuan data yang akan digunakan untuk proses KDD dilakukan pada tahap ini. Mencari data yang tersedia, memperoleh data tambahan yang dibutuhkan, mengintegrasikan semua data untuk KDD ke dalam sebuah data set, termasuk atribut yang diperlukan dalam proses KDD. Terdapat interaktif dan iteratif dari KDD tersebut. Dimulai dengan data yang tersedia baik mengatur dan kemudian mengembang dan mengamati efeknya dalam KDD 3. Preprocessing dan cleansing. Dalam tahap ini kehandalan data ditingkatkan. Termasuk data clearing, seperti menangani data yang tidak lengkap, menghilangkan gangguan atau outlier. Termasuk mengunakan metode statistik yang kompleks, atau melakukan penambangan spesifik data dengan algoritma dalam KDD 4. Transformasi data. Pada tahap ini, generasi data yang lebih baik untuk data mining dipersiapkan dan dikembangkan, membuat data menjadi lebih baik menggunakan metode reduksi dimensi dan transformasi atribut. Sebagai contoh, dalam pemeriksaan medis, hasil bagi atribut mungkin sering menjadi faktor yang paling penting, dan tidak satu persatu. Di pemasaran, kita mungkin perlu mempertimbangkan efek di luar kendali kita serta upaya dan temporal isu (seperti mempelajari pengaruh akumulasi iklan). Namun, bahkan jika kita tidak menggunakan transformasi yang tepat di awal, kita dapat memperoleh efek mengejutkan bahwa petunjuk kepada kita tentang transformasi diperlukan (Pada iterasi berikutnya). Dengan demikian proses KDD mencerminkan kepada dirinya sendiri dan menyebabkan pemahaman tentang transformasi yang dibutuhkan (seperti pengetahuan ringkas dari sebuah ahli dalam bidang tertentu mengenai indikator terkemuka kunci). 5. Memilih tugas data mining yang cocok. Pada tahap ini ditentukan tipe data mining yang akan digunakan, apakah klasifikasi, regresi, atau clustering, tergantung pada tujuan KDD dan tahap sebelumnya. 6. Memilih algoritma data mining. Pemilihan algoritma yang paling tepat untuk menemukan pola dilakukan pada tahap ini. Ada dua tujuan utama dalam Data Mining: prediksi dan deskripsi. Prediksi sering disebut sebagai Supervised Data Mining, sementara deskriptif Data Mining meliputi aspek-aspek unSupervised dan visualisasi Data Mining. Sebagian besar data teknik pertambangan didasarkan pada pembelajaran induktif, dimana model yang dibangun secara eksplisit maupun implisit oleh generalisasi dari jumlah yang memadai pelatihan data training. Asumsi yang mendasari pendekatan induktif adalah bahwa model terlatih ini berlaku untuk kasus masa depan. Strategi ini juga memperhitungkan tingkat meta-learning untuk set tertentu dari data yang tersedia. 7. Penggunaan algoritma data mining. Pada tahap ini dilakukan implementasi dari algoritma data mining yang telah ditentukan pada tahap sebelumnya. Misalnya dengan menseting parameter kontrol algoritma, seperti jumlah minimum kasus dalam daun tunggal dari pohon keputusan. 8. Evaluasi. Pada tahap ini dilakukan evaluasi dan penerjemahan dari pola yang diperoleh, sehubungan dengan tujuan yang ditetapkan pada langkah pertama. Langkah ini berfokus pada komprehensibilitas dan kegunaan dari model induksi. Pada langkah ini pengetahuan ditemukan juga terdokumentasi untuk penggunaan lebih lanjut. Langkah terakhir adalah penggunaan dan umpan balik secara keseluruhan pada pola dan hasil penemuan diperoleh dengan data mining. 9. Penggunaan pengetahuan yang ditemukan yakni memasukkan pengetahuan ke dalam sistem lain untuk ditindaklanjuti. Pengetahuan menjadi aktif dalam arti bahwa kita dapat membuat perubahan ke sistem dan mengukur dampak Sebenarnya keberhasilan langkah ini menentukan efektivitas proses KDD secara keseluruhan. Ada banyak tantangan dalam langkah ini, seperti kehilangan "kondisi laboratorium". Misalnya, pengetahuan itu ditemukan dari sebuah snapshot statis tertentu (biasanya sampel) dari data, tapi sekarang data menjadi dinamis.

\section{HASIL DAN PEMBAHASAN}

attribut yang diperoleh dari hasil kunjungan adalah sebagai berikut: harga, jumlah seater atau jumlah penumpang, jenis mobil, bahan bakar, penggerak roda, getaran, kondisi body mobil, perseneling, jumlah kilometer, modifikasi, asuransi dan label hasil.

Tabel 2. Attribut Data Mahasiswa

\begin{tabular}{|l|l|}
\hline Attribut & Kriteria \\
\hline Harga & $<100$ \\
& $100-200$ \\
\hline
\end{tabular}




\begin{tabular}{|c|c|}
\hline & $200-300$ \\
\hline & $400-500$ \\
\hline & $>500$ \\
\hline Jumlah & 5 Penumpang \\
\hline Penumpang & 7 Penumpang \\
\hline Jenis Mobil & SUV \\
\hline & Sedan \\
\hline & Minibus \\
\hline Bahan Bakar & Bensin \\
\hline & Solar \\
\hline & Hybrid \\
\hline Penggerak Roda & Penggerak Depan \\
\hline & $\begin{array}{l}\text { Penggerak Belakang } \\
\text { 4WD }\end{array}$ \\
\hline Getaran & Lembut \\
\hline & Tidak Ada \\
\hline & Kasar \\
\hline Kondisi Body & Mengkilap \\
\hline mobil & Warna Pudar \\
\hline & Cat Rusak \\
\hline Perseneling & Kasar \\
\hline & Lembut \\
\hline & Halus \\
\hline Kilometer & $<50000$ \\
\hline & $\begin{array}{l}50000-100000 \\
>100000\end{array}$ \\
\hline
\end{tabular}

Dari attribut pada tabel 2 digunakan untuk diolah dalam perangkat lunak Rapidminer 5.1 sebagai berikut:

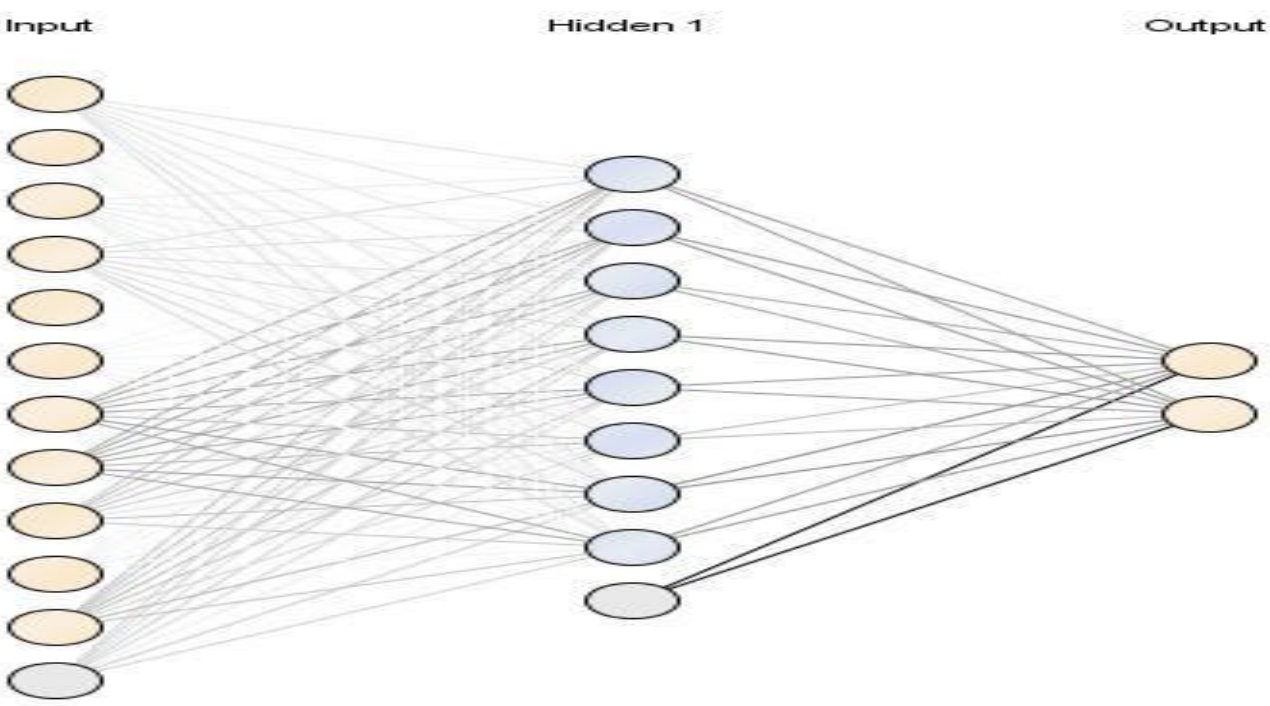

Gambar 2. Neural Net yang dihasilkan

Berikut hasil perhitungan pada setiap node:

Hidden 1

Node 1 (Sigmoid)

Harga: 0.532

Jumlah Penumpang: 0.153

Jenis Mobil: -0.382
Bahan Bakar: 0.705

Penggerak Roda: 0.024

Getaran: 0.150

Kondisi Body Mobil: -1.621

Perseneling: -1.581

Kilometer: 0.971

Modifikasi: -0.191

Asuransi: -1.086
Threshold: 0.697

Node 2 (Sigmoid)

Harga: 0.528

Jumlah Penumpang: 0.136

Jenis Mobil: -0.360

Bahan Bakar: 0.695 
Penggerak Roda: 0.019

Getaran: 0.227

Kondisi Body Mobil: -1.741

Perseneling: -1.677

Kilometer: 1.099

Modifikasi: -0.178

Asuransi: -1.143

Threshold: 0.764

Node 3 (Sigmoid)

Harga: 0.414

Jumlah Penumpang: 0.143

Jenis Mobil: -0.421

Bahan Bakar: 0.647

Penggerak Roda: 0.051

Getaran: 0.163

Kondisi Body Mobil: -1.527

Perseneling: -1.517

Kilometer: 0.857

Modifikasi: -0.246

Asuransi: -0.934

Threshold: 0.564

Node 4 (Sigmoid)

Harga: 0.525

Jumlah Penumpang: 0.196

Jenis Mobil: -0.356

Bahan Bakar: 0.731

Penggerak Roda: 0.054

Getaran: 0.219

Kondisi Body Mobil: -1.710

Perseneling: -1.714

Kilometer: 1.106

Modifikasi: -0.147

Asuransi: -1.217

Threshold: 0.785

Node 5 (Sigmoid)

Harga: 0.474
Jumlah Penumpang: 0.171

Jenis Mobil: -0.326

Bahan Bakar: 0.650

Penggerak Roda: 0.038

Getaran: 0.137

Kondisi Body Mobil: -1.615

Perseneling: -1.661

Kilometer: 0.925

Modifikasi: -0.165

Asuransi: - 1.080

Threshold: 0.710

Node 6 (Sigmoid)

Harga: 0.391

Jumlah Penumpang: 0.147

Jenis Mobil: -0.289

Bahan Bakar: 0.572

Penggerak Roda: -0.025

Getaran: 0.156

Kondisi Body Mobil: -1.243

Perseneling: -1.336

Kilometer: 0.503

Modifikasi: -0.327

Asuransi: -0.744

Threshold: 0.320

Node 7 (Sigmoid)

Harga: 0.563

Jumlah Penumpang: 0.256

Jenis Mobil: -0.393

Bahan Bakar: 0.761

Penggerak Roda: 0.090

Getaran: 0.239

Kondisi Body Mobil: -1.830

Perseneling: -1.802

Kilometer: 1.211

Modifikasi: -0.155

Asuransi: -1.330

Threshold: 0.939
Node 8 (Sigmoid)

Harga: 0.530

Jumlah Penumpang: 0.233

Jenis Mobil: -0.371

Bahan Bakar: 0.692

Penggerak Roda: 0.006

Getaran: 0.218

Kondisi Body Mobil: -1.675

Perseneling: -1.719

Kilometer: 1.019

Modifikasi: -0.180

Asuransi: -1.116

Threshold: 0.833

Output

Class 'Layak' (Sigmoid)

Node 1: 1.870

Node 2: 2.049

Node 3: 1.702

Node 4: 2.073

Node 5: 1.902

Node 6: 1.279

Node 7: 2.323

Node 8: 2.040

Threshold: -4.910

Class 'Tidak Layak' (Sigmoid)

Node 1: -1.887

Node 2: -2.059

Node 3: -1.707

Node 4: -2.095

Node 5: -1.886

Node 6: -1.291

Node 7: -2.288

Node 8: -2.031

Threshold: 4.910

\section{SIMPULAN DAN SARAN}

Dari hasil pengujuan sebanyak 1300 record data yang diambil dari penjual mobil bekas maka diperoleh tingkat akurasi, presisi dan recall mencapai $100 \%$ hal tersebut tergolong klasifikasi exelent karena nilai yang dicapai yakni setara dengan $0.90-1.00$ (Gorunescu, 2011). Seluruh node pelatihan ditiap jaringan syaraf menunjukan nilai yang maksimal. Berdasarkan habit atau kebiasaan maka dengan ini setiap rule yang ada disarankan untuk dapat dimasukan dalam perancangan perangkat lunak aplikasi.

\section{DAFTAR PUSTAKA}

Darudiato, S., Santoso, S. W., \& Wiguna, S. (2002). BUSINESS INTELLIGENCE : KONSEP DAN METODE, (9), 63-67.

Dhika, H. (2016). MODELS FEASIBILITY OF PROVIDING SCHOLARSHIP. CommIT, X(X), 101-102.

Dhika, H., Destiawati, F., \& Fitriansyah, A. (2016). Implementasi Algoritma C4.5 Terhadap Kepuasan Pelanggan. SNAPP 2016, Vol. 6(Sains dan Teknologi), 16-22.

Gorunescu, F. (2011). Data mining: Concepts, models and techniques. Intelligent Systems Reference Library, 
12. https://doi.org/10.1007/978-3-642-19721-5

Hagan, M. T., Demuth, H. B., \& Beale, M. H. (1995). Neural Network Design. Boston Massachusetts PWS,

2, 734. https://doi.org/10.1007/1-84628-303-5

Yu, Z. (Jerry), Haghighat, F., \& Fung, B. C. M. (2016). Advances and challenges in building engineering and data mining applications for energy-efficient communities. Sustainable Cities and Society, 25, 33-38. https://doi.org/10.1016/j.scs.2015.12.001 